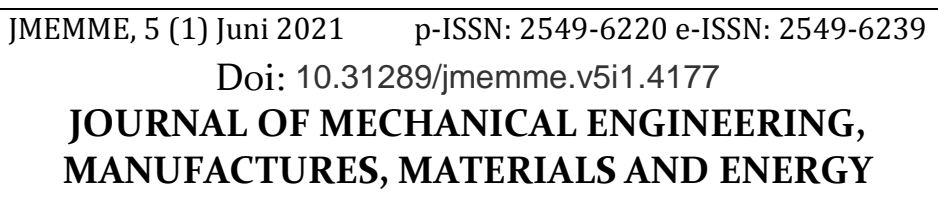

\title{
Conveyor Pengangkut Sampah Otomatis dengan Load Cell dan Flow Sensor
}

\section{Automatic Garbage Conveyor with Load Cell and Flow Sensor}

\author{
Catur Harsito ${ }^{1 *}$, Albert Xaverius ${ }^{2}$, Singgih Dwi Prasetyo ${ }^{3}$, Pipit Wulansari ${ }^{4}$, Johan Alfian \\ Pradana ${ }^{5}$ \\ 1Vokasi Teknik Mesin, Universitas Sebelas Maret \\ 1,2,3Program Studi Teknik Mesin, Fakultas Teknik, Universitas Sebelas Maret \\ 5Program Studi Teknik Industri, Fakultas Teknik, Universitas Kediri \\ Diterima: 25-08-2020 ; Disetujui: 15-02-2021 ; Diterbitkan: 06-05-2021 \\ *Corresponding author: catur_harsito@staff.uns.ac.id
}

\begin{abstract}
Abstrak
Sampah tentunya sudah menjadi masalah klasik dari dulu hingga sekarang yang cenderung makin parah dari tahun ke tahun khususnya di daerah Jabodetabek. Berbagai upaya dilakukan untuk membereskan masalah sampah di kota - kota. Hal ini menimbulkan keinginan penulis untuk membuat suatu alat yang dapat membersihkan sampah di sungai secara otomatis, jangkauan jauh, dan efektif yaitu conveyor pengangkat sampah. Dengan rancangan ini, sampah dapat dibersihkan terus - menerus karena sistem otomatisnya bahkan, jika volume sampah pada sungai tersebut bertambah, alat yang penulis rancang dapat menambah sendiri kecepatan pembersihan sampahnya. Tentunya dengan adanya sistem sensor, alat dapat terus beroperasi, tanpa membiarkan sampah tertumpuk, menggunakan energi secara efektif, dan tidak membutuhkan banyak tenaga kerja manusia. Alat yang dirancang memiliki jangkauan seluruh sungai serta alat ini mampu dibongkar pasang. Berhubung alat yang penulis rancang dapat berjalan secara otomatis, hanya dibutuhkan 1 sampai 2 tenaga kerja yang tugasnya hanya mengawasi dan tak perlu bekerja fisik. Alat ini juga mudah dioperasikan. Untuk menghidupkan alat ini tidak perlu keterampilan khusus seperti kemampuan mengendarai ketika menggunakan excavator.
\end{abstract}

Kata Kunci: conveyor, excavator, sampah

\begin{abstract}
Garbage has certainly been a classic problem which tends to get worse, especially in Jabodetabek area. Various attempts were made to solve the waste problem in the cities. This raises the writer's desire to make a tool that can clean trash in the river automatically, far-reaching, and effectively, namely the lifting garbage conveyor. With this design, garbage can be cleaned continuously because of the automatic system. Even if the volume of garbage in the river increases, the tool can increase the speed of cleaning the garbage by itself. With the sensor system, the tool can continue to operate, without allowing trash to accumulate, using energy effectively, and not requiring a lot of human labor. This tool is designed to cover the entire river and it is capable of being assembled. Because the tool can run automatically, it only takes 1 to 2 workers whose supervise and do not need to work physically. This tool is easy to operate. To start this tool, you don't need special skills such as the ability to drive when using an excavator.
\end{abstract}

Keyword: conveyor, excavator, garbage

How to Cite: Harsito, C., 2021. Conveyor Pengangkut Sampah Otomatis dengan Load Cell dan Flow Sensor. JMEMME (Journal of Mechanical Engineering, Manufactures, Materials and Energy). 4 (1): 18-33 


\section{Catur Harsito, Conveyor Pengangkut Sampah Otomatis dengan...}

\section{PENDAHULUAN}

Sumber sampah pada perkotaan biasanya merupakan sampah yang dihasilkan oleh perumahan, pasar, pertokoan/jasa, fasilitas kesehatan, Industri, dan pertamanan. Dari tahun ke tahun sampah sudah semakin banyak khususnya di daerah perkotaan Indonesia. Untuk memberikan gambaran, total sampah yang dihasilkan kota DKI Jakarta pada tahun 2013 adalah sebesar 6,513.85 ton/hari dengan sampah terangkut 5,636.90 ton/hari dan sampah yang tidak terangkut 876.95 ton/hari [1]. Dengan banyaknya sampah yang tidak terangkut, akan ada banyak sampah yang terbuang ke sungai setiap harinya. Salah satu dampak yang diakibatkan dari sampah yang terbuang ke sungai adalah menurunnya kualitas air yang dapat dilihat dari parameter seperti ph, warna, bau, dan lainnya [2]. Padahal, pencemaran sungai sebagian besar disebabkan oleh masyarakat itu sendiri, pencemaran yang dilakukan justru akan membuat sungai tidak dapat dimanfaatkan untuk memenuhi kebutuhan dan bahkan akan menjadi sebab mewabahnya suatu penyakit. Maka dari itu, perlu adanya upaya dalam mencegah sampah masuk ke sungai ataupun membersihkan sungai dari sampah yang ada. Meninjau penelitian Surya [3], sampah perlu proses pengolahan jika hendak difungsikan kembali. Sehingga, dapat memberikan guna bagi penggunanya [4], [5]. Dengan demikian, sebuah peralatan harus diciptakan sebagai langkah utama.

Rancangan yang penulis buat untuk mengatasi masalah jangkauan dengan menggunakan kubus apung agar tidak ada sampah yang dapat lolos seperti pada desain kapal. Tetapi, penulis membuat inovasi dengan menambah screw conveyor pada kubus apung ini. Dengan menggunakan screw conveyor, dapat mengatasi masalah sampah yang tertumpuk ketika menggunakan kubus apung. Walaupun rancangan ini terdiri dari dua bagian pengangkat (screw conveyor dan belt conveyor), rancangan ini menggunakan transmisi yang memungkinkan kedua bagian tersebut untuk terhubung dan beroperasi dengan satu sumber daya[6]. Sumber daya yang di gunakan dalam rancangan ini bukan bahan bakar fosil sehingga dapat megatasi masalah pencemaran lingkungan yang di timbulkan dari menggunakan desain kapal atau excavator. Berdasarkan beberapa penelitian yang telah dilakukan [7]-[10], menyatakan sebuah conveyor memerlukan analisa keandalan. Dengan demikian, asumsi dan target dari membuat rancangan menyangkut keandalan, perhitungan biaya dan model rancangan yang tepat serta cara menggunakan yang tidak menyulitkan pengguna [11]. Rancangan ini akan dilengkapi dengan dua sensor untuk mendeteksi berat beban yang di terima alat, dan kecepatan arus pada sungai tersebut sehingga alat dapat mengubah kecepatan pengangkatan sampah. sensor ini juga memungkinkan alat untuk berhenti bekerja secara otomatis ketika kecepatan arus atau beban yang di terima alat tidak memungkinkan untuk terus mengoperasikan alat atau akan membuat alat rusak. Hal ini sebagai bentuk sistem penanggulangan alat pada situasi darurat. Tujuan utama di bentuknya rancangan ini adalah untuk membersihkan sampah di permukaan sungai secara efisien, efektif, ramah lingkungan, dan tidak banyak menggunakan sumber daya manusia. Untuk mencapai itu, terdapat beberapa persyaratan rancangan yang dibutuhkan. Persyaratan rancangan yang 
dibutuhkan adalah rancangan harus dapat mengapung di permukaan sungai. Rancangan juga perlu sistem pengangkatan yang tidak membiarkan ada sampah yang lolos sehingga lebih efektif. Bahan bakar penggerak yang digunakan harus ramah lingkungan dan perlu sistem otomasi pada rancangan ini.

\section{METODE PENELITIAN}

Alat yang penulis rancang ini adalah sebuah conveyor pengangkat sampah sungai dengan sambungan transmisi gearbox-universal coupling dan sensor pengatur kecepatan[12]. Fungsi utama dari alat yang penulis rancang ini adalah untuk mengangkat sampah yang ada di permukaan air sungai secara otomatis ke darat. Bagian penggerak dalam alat ini adalah motor listrik ac yang menggunakan arus AC (Alternating Current) sebagai sumber dayanya. bagian conveyor belt. Conveyor belt ini terdiri dari body conveyor belt kanan dan kiri yang merupakan plat baja ringan yang juga di potong dan di las sesuai ukuran dan bentuknya. Bagian screw conveyor dalam rancangan ini berada di air. Screw conveyor ini terdiri dari body yang merupakan plat HDPE (high density polyethylene) yang di bengkokkan dan di beri lubang lubang agar dapat di ikat pada kubus apung. Bagian transmisi ini terdiri dari gabungan dari gearbox dan universal coupling. Bagian terakhir dalam rancangan ini adalah bagian kubus apung dan penyambungnya. Kubus apung dan penyambungnya pada umumnya di pasaran terbuat dari HDPE (High Density Polyethylene). Kubus apung ini dapat di susun berjejer sepanjang sungai sebanyak yang di butuhkan. Kubus apung ini sangat baik dalam menahan beban karena orang dapat berdiri di atasnya dan kubus tidak akan tenggelam. Ketika semua rangkaian ini berjalan, sampah yang tertahan pada kubus apung akan di gerakkan oleh screw conveyor. Sampah yang di gerakkan ini akan bergerak ke pinggir menuju arah conveyer belt.

\section{HASIL DAN PEMBAHASAN}

Berdasarkan persyaratan rancangan tersebut, terdapat beberapa sketsa yang penulis buat sebagai gambaran umum sebelum membuat rancangan yang ada sekarang ditunjukkan pada Gambar 1, Gambar 2 dan Gambar 3. Berdasarkan sketsa awal rancangan dibutuhkan selective design criteria untuk menentukan sketsa mana yang akan digunakan untuk dijadikan rancangan yang lebih terperinci. Penulis menggunakan metode House of Quality dalam menentukan selective design criteria yang di butuhkan untuk rancangan Sketsa.

Di bandingkan dengan alat yang sudah ada, rancangan yang penulis buat unggul dalam konsistensi pengangkutan sampah lebih banyak dibandingkan dengan alat yang sudah ada sebelumnya. Hal ini berhubungan dengan waktu alat bekerja yang menjadi hal terpenting dalam penilaian house of quality seperti pada Gambar 4 dimana alat ini dapat bekerja setiap saat. Terakhir adalah desain rancangan ini yang memungkinkan untuk di bongkar pasang dan menyesuaikan ukuran alat dengan lebar sungai. 
Catur Harsito, Conveyor Pengangkut Sampah Otomatis dengan...

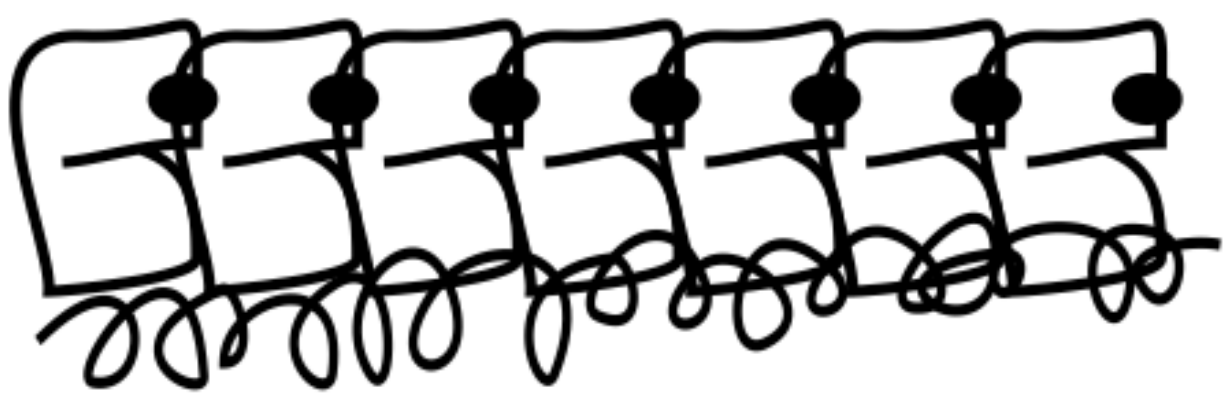

Gambar 1. Rancangan sketsa 1

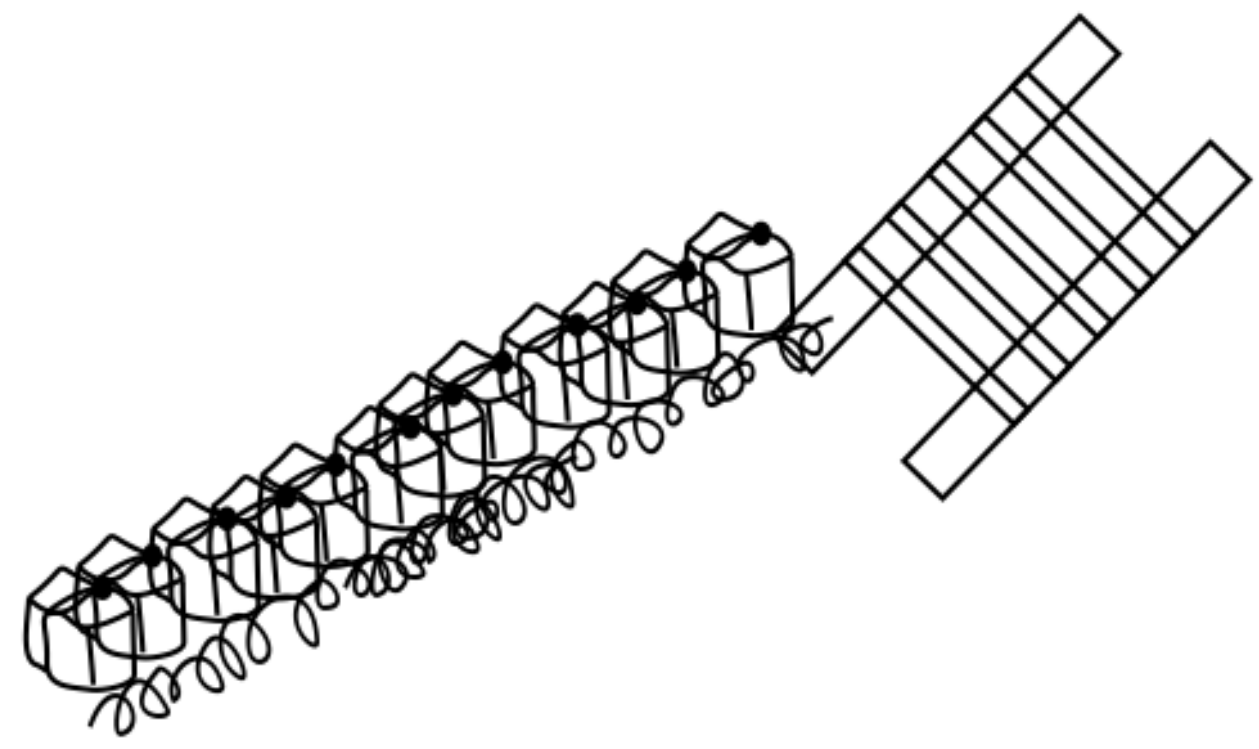

Gambar 2. Rancangan sketsa 2

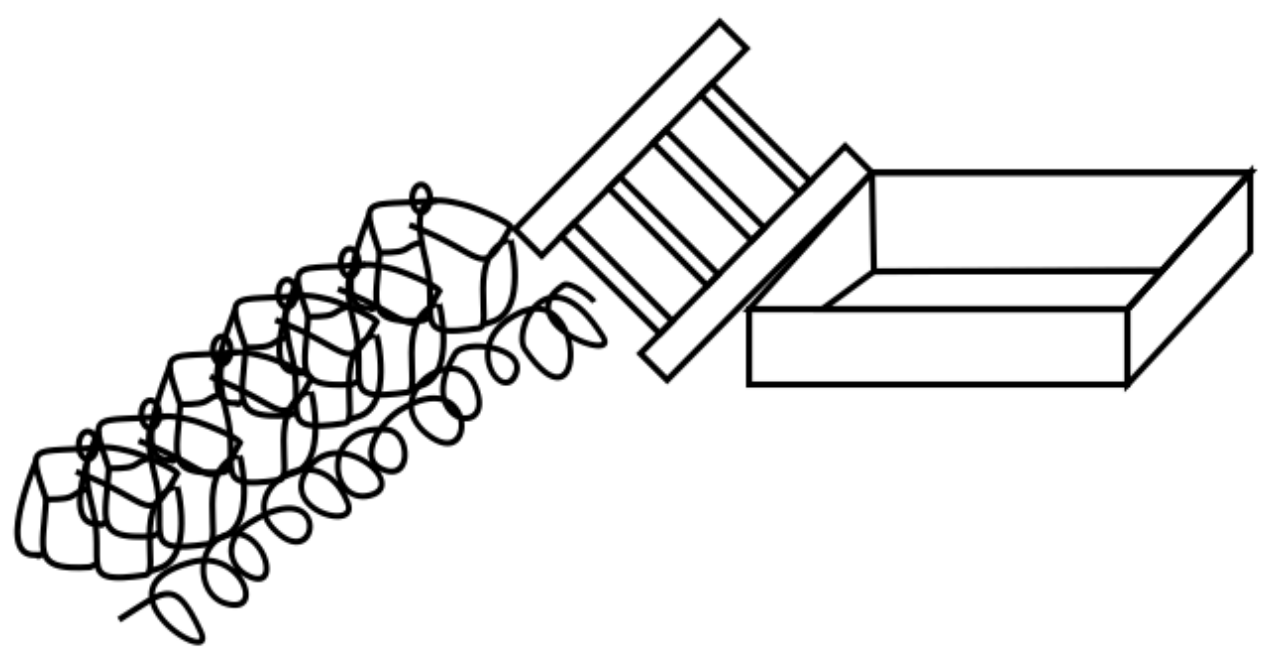

Gambar 3.Rancangan sketsa 3 


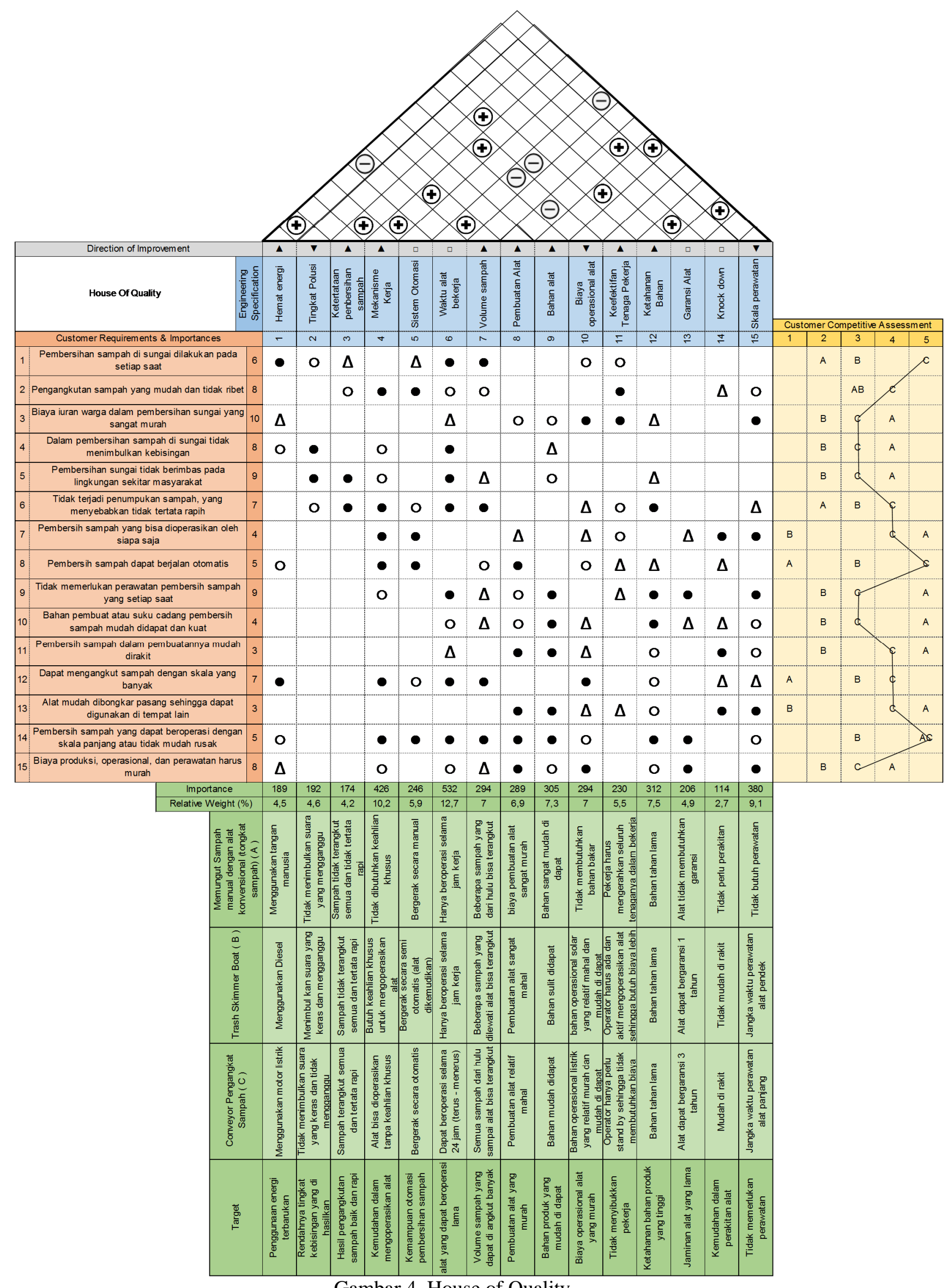

Gambar 4. House of Quality 


\section{Catur Harsito, Conveyor Pengangkut Sampah Otomatis dengan...}

Setelah menentukan kriteria pembuatan desain dilakukan perhitungan mulai dari conveyor belt. Dimensi yang akan digunakan dalam perhitungan daya yang dibutuhkan oleh conveyor belt ditunjukkan pada Tabel 1. Data massa jenis rata- rata sampah berada pada sungai Cikapundung [13].

Tabel 1. Bagan Keterangan Conveyor Belt

\begin{tabular}{cccc}
\hline Parameter & Nilai & Unit & Keterangan \\
\hline$D$ & 120 & $\mathrm{~mm}$ & diameter roller conveyor belt \\
\hline$l$ & 3300 & $\mathrm{~mm}$ & panjang satu bagian conveyor belt \\
\hline$p$ & 890 & $\mathrm{~mm}$ & lebar belt \\
\hline$t$ & 76,87 & $\mathrm{~mm}$ & tinggi pitch conveyor belt \\
\hline$N$ & 40 & $\mathrm{rpm}$ & kecepatan putar conveyor belt \\
\hline$n$ & 10 & & jumlah pitch conveyor belt \\
\hline$\rho_{1}$ & 87 & $\mathrm{~kg} / \mathrm{m}^{3}$ & massa jenis rata - rata sampah yang masuk ke \\
& & & sungai setiap hari \\
\hline$\pi$ & 3,14 & & phi \\
\hline$j$ & 0,8 & & koefisien pengisian pitch conveyor belt \\
\hline$g$ & 9,8 & $\mathrm{~m} / \mathrm{s}^{2}$ & percepatan gravitasi \\
\hline
\end{tabular}

Setelah menentukan dimensi rancangan yang akan di buat, terdapat spesifikasi yang penulis buat untuk rancangan pada bagian conveyor belt yang akan digunakan dalam perhitungan daya. Spesifikasi tersebut dapat di lihat pada Tabel 2.

Tabel 2. Spesifikasi Conveyor Belt

\begin{tabular}{cccc}
\hline No & Parameter & Rumus & Hasil \\
\hline 1 & Panjang belt & $L=2 l+\pi D$ & $6,9768 \mathrm{~m}$ \\
\hline 2 & Jarak antar pitch & $p_{b}=\frac{L}{2}: 10$ & $0,34884 \mathrm{~m}$ \\
\hline 3 & $\begin{array}{c}\text { Volume yang dapat } \\
\text { di angkat per pitch }\end{array}$ & $V=p \times p_{b} \times t$ & $0,113 \mathrm{~m}^{3}$ \\
\hline \multirow{3}{*}{$\begin{array}{c}\text { Berat sampah } \\
\text { maksimum per } \\
\text { pitch }\end{array}$} & $m_{c}=V \rho_{1} j$ & $7,9 \mathrm{~kg}$ \\
\hline
\end{tabular}

Dengan asumsi beban conveyor belt berada pada beban maksimum. Perhitungan daya ini dilakukan dengan mengkalkulasi beban gaya yang di terima conveyor belt ketika semua belt bagian atasnya terisi sampah sehingga torsi yang di alami ole roller conveyor dapat dihitung begitu pula dengan dayanya pada kecepatan sudut (N) $40 \mathrm{rpm}$. Dari hasil perhitungan, daya yang di dapat adalah 486,44 Watt yang berarti daya yang di butuhkan setara dengan 0,652 HP (Horse Power) seperti ditunjukkan pada Tabel 3.

Tabel 3. Bagan perhitungan daya conveyor belt

\begin{tabular}{cccc}
\hline No & Parameter & Rumus & Hasil \\
\hline 1 & $\begin{array}{c}\text { Kecepatan } \\
\text { linier belt }\end{array}$ & $v=\frac{d \times N}{60}$ & $0,25 \mathrm{~m} / \mathrm{s}$ \\
\hline 2 & $\begin{array}{c}\text { Kapasitas screw } \\
\text { conveyor }\end{array}$ & $Q=\frac{m_{c} v}{p_{b}}$ & $5,66 \mathrm{~kg} / \mathrm{s}$ \\
\hline 3 & $\begin{array}{c}\text { Daya } \\
\text { penggerak }\end{array}$ & $P=\frac{2 \pi m_{c} g n N D}{60 \times 2}$ & 194,577 Watt \\
\hline 4 & Daya aktual & $P_{d}=s f \times P$ & 486,44 Watt \\
\hline
\end{tabular}


Dimensi yang akan digunakan dalam perhitungan daya yang dibutuhkan oleh screw conveyor ditunjukkan pada Tabel 4. Data massa jenis rata- rata sampah dan volume rata rata perharinya diambil pada sungai Cikapundung [13].

Tabel 4. Bagan keterangan screw conveyor

\begin{tabular}{|c|c|c|c|}
\hline Parameter & Nilai & Unit & Keterangan \\
\hline$D$ & 338 & $\mathrm{~mm}$ & diameter luar screw \\
\hline$d$ & 50 & $\mathrm{~mm}$ & diameter poros screw \\
\hline$N$ & 40 & rpm & kecepatan putar screw \\
\hline$n$ & 12 & & jumlah pitch screw \\
\hline$\rho_{1}$ & 87 & $\mathrm{~kg} / \mathrm{m}^{3}$ & $\begin{array}{c}\text { massa jenis rata - rata sampah yang masuk ke } \\
\text { sungai setiap hari }\end{array}$ \\
\hline$V_{1}$ & 21,95 & $m^{3}$ & $\begin{array}{c}\text { volume rata - rata sampah yang masuk ke sungai } \\
\text { setiap hari }\end{array}$ \\
\hline$L_{2}$ & 2436 & $\mathrm{~mm}$ & panjang daun screw conveyor \\
\hline$\pi$ & 3,14 & & phi \\
\hline$A_{1}$ & $2,29 \times 10^{6}$ & $\mathrm{~mm}^{2}$ & luas permukaan daun screw conveyor \\
\hline$m$ & 37,52 & $\mathrm{~kg}$ & berat screw conveyor \\
\hline$g$ & 9,8 & $\mathrm{~m} / \mathrm{s}^{2}$ & percepatan gravitasi \\
\hline
\end{tabular}

Setelah menentukan dimensi rancangan yang akan di buat, terdapat spesifikasi yang penulis buat untuk rancangan pada bagian conveyor belt yang akan digunakan dalam perhitungan daya. Spesifikasi tersebut dapat di lihat pada Tabel 5.

Tabel 5. Spesifikasi Screw Conveyor

\begin{tabular}{cccc}
\hline No & Parameter & Rumus & Hasil \\
\hline 1 & $\begin{array}{c}\text { Lebar pitch } \\
\text { screw }\end{array}$ & $p_{c}=\frac{L_{2}}{n}$ & $203 \mathrm{~mm}$ \\
\hline 2 & $\begin{array}{c}\text { Sudut } \\
\text { kemiringan } \\
\text { screw }\end{array}$ & $\alpha=\tan ^{-1}\left(\frac{P}{\pi\left(\frac{D+d}{2}\right)}\right)$ & $18,4^{\circ}$ \\
\hline 3 & $\begin{array}{c}\text { Luas ruang } \\
\text { penyalur }\end{array}$ & $A=\left(\frac{\pi D^{2}}{4}\right)-\left(\frac{\pi d^{2}}{4}\right)$ & $\begin{array}{l}0,087 \\
\times 10^{6} \mathrm{~mm}^{2}\end{array}$ \\
\hline
\end{tabular}

Hal ini diperlukan untuk memperhitungkan beban gaya yang dialami oleh screw conveyor saat menggerakkan sampah ke samping menuju bagian conveyor belt. Dari hasil perhitungan seperti ditunjukkan pada Tabel 6, daya yang di dapat adalah 459,68 Watt berarti daya yang di butuhkan setara dengan 0,616 HP (Horse Power).

Tabel 6. Bagan perhitungan screw conveyor

\begin{tabular}{cccc}
\hline No & Parameter & Rumus & Hasil \\
\hline 1 & $\begin{array}{c}\text { Kecepatan } \\
\text { putaran }\end{array}$ & $v=\frac{P \times N}{60}$ & $135,33 \mathrm{~mm} / \mathrm{s}$ \\
\hline 2 & $\begin{array}{c}\text { Kapasitas } \\
\text { screw } \\
\text { conveyor }\end{array}$ & $Q=\rho_{1} v A_{1} 0,5$ & $13,48 \mathrm{~kg} / \mathrm{s}$ \\
\hline 3 & $\begin{array}{c}\text { Daya } \\
\text { penggerak }\end{array}$ & $P=\frac{2 \pi \rho_{1} V_{1} v N D}{60 \times 2}$ & $183,87 \mathrm{Watt}$ \\
\hline 4 & Daya aktual & $P_{d}=s f \times P$ & 459,68 Watt \\
\hline
\end{tabular}




\section{Catur Harsito, Conveyor Pengangkut Sampah Otomatis dengan...}

Didapatkan total daya yang dibutuhkan rancangan adalah 1,268 HP. Dari perhitungan daya yang di dapatkan, spesifikasi motor listrik yang diperlukan adalah motor listrik 1,5 HP dengan 3 fase. Motor listrik yang digunakan adalah 3 fase karena motor jenis ini yang biasa di pakai pada rangkaian conveyor karena kekuatannya [14]. Motor ini berputar pada $3000 \mathrm{rpm}$.

Berhubung spesifikasi putaran motor terlalu tinggi untuk di pasang pada rangkaian conveyor, speed reducer yang digunakan pada motor listrik memliki perbandingan gigi 75 : 1 agar kecepatan motor dari 3000 rpm bisa menjadi 40 rpm sesuai pada nilai kecepatan putar $(\mathrm{N})$ screw conveyor dan conveyor belt. Berhubung nilai kecepatan putar pada screw conveyor maupun conveyor belt adalah sama, maka perbandingan gigi pada gearbox dengan universal coupling penyambung kedua rangkaian tersebut adalah 1: 1. Perhitungan statis diperlukan dalam menentukan beban maksimum rancangan yang diterima ketika beroperasi. Data yang dibutuhkan dalam analisa statis ditunjukkan pada Tabel 7.

Tabel 7. Bagan Keterangan Analisa Statis

\begin{tabular}{cccc}
\hline Parameter & Rumus & Hasil & Keterangan \\
\hline $\begin{array}{c}\text { Beban merata screw } \\
\text { conveyor }\end{array}$ & $F_{1}=\frac{m_{c} n g}{l_{1}}$ & $98,4 \mathrm{~N} / \mathrm{m}$ & $\begin{array}{c}\text { Keterangan simbol dapat dilihat } \\
\text { pada tabel 4 }\end{array}$ \\
\hline $\begin{array}{c}\text { Beban merata conveyor } \\
\text { Belt }\end{array}$ & $F_{2}=\frac{\rho_{1} V_{1} v}{l_{2}}$ & $234,6 \mathrm{~N} / \mathrm{m}$ & $\begin{array}{c}\text { Keterangan simbol dapat dilihat } \\
\text { pada tabel 4 }\end{array}$ \\
\hline Panjang screw & $l_{1}$ & $2,62 \mathrm{~m}$ & Dimensi rancangan \\
\hline Panjang Belt & $l_{2}$ & $3,3 \mathrm{~m}$ & Dimensi rancangan \\
\hline
\end{tabular}

Teknik analisa statis yang penulis pakai untuk pemilihan material rancangan ini adalah dengan analisa BMD (Bending Moment Diagram), SFD (Shear Force Diagram), dan NFD (Normal Force Diagram). Normal Force Diagram dalam analisa ini tidak diperhitungkan karena tidak ada gaya tekan atau tarik yang berarti pada analisa rancangan ini. Untuk memudahkan analisa, penulis menyederhanakan free body diagram kedua bagian conveyor menjadi bentuk batang atau poros dengan dua tumpuan seperti Gambar 5. Hasil analisis statik yang telah dihitung pada rangakaian konveyor ditunjukkan pada Tabel 8.

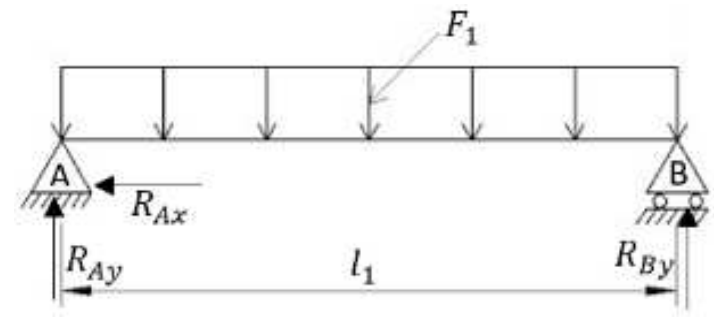

(a)

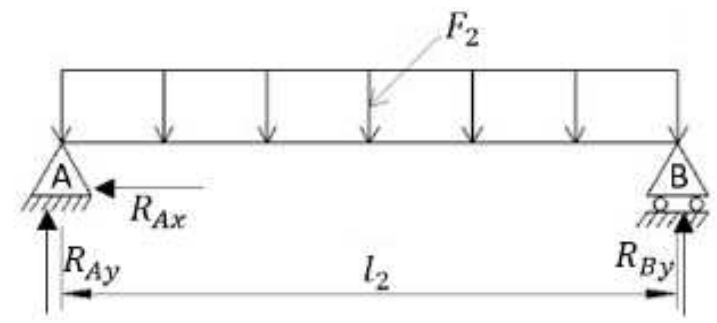

(b)

Gambar 5. Analisa statis (a) screw conveyor dan (b) conveyor belt 
Tabel 8 Analisa statis rangkaian conveyor

\begin{tabular}{|c|c|c|c|}
\hline Parameter & Rumus & Hasil & Keterangan \\
\hline $\begin{array}{c}\text { Gaya Reaksi } \\
\text { screw conveyor }\end{array}$ & $\begin{array}{c}R_{A y}+R_{B y}=F_{1} l_{1} \\
R_{B y}=\frac{F_{1} l_{1} l_{1}}{l_{1} 2}\end{array}$ & $\begin{array}{l}R_{A y}=128,9 \mathrm{~N} \\
R_{B y}=128,9 \mathrm{~N}\end{array}$ & $\begin{array}{c}\text { Keterangan simbol } \\
\text { dapat dilihat pada } \\
\text { tabel } 7\end{array}$ \\
\hline $\begin{array}{l}\text { Gaya Reaksi } \\
\text { conveyor belt }\end{array}$ & $\begin{array}{c}R_{A y}+R_{B y}=F_{2} l_{2} \\
R_{B y}=\frac{F_{2} l_{2} l_{2}}{l_{2} 2}\end{array}$ & $\begin{array}{l}R_{A y}=387,1 N \\
R_{B y}=387,1 N\end{array}$ & $\begin{array}{c}\text { Keterangan simbol } \\
\text { dapat dilihat pada } \\
\text { tabel } 7\end{array}$ \\
\hline $\begin{array}{r}\text { Rumus } \\
\text { BMD } s \\
\text { conve }\end{array}$ & $M_{x}=\left(R_{A y} x\right)-\left(\frac{F_{1} x^{2}}{2}\right)$ & $M_{1 \max }=$ & $\begin{array}{c}\text { Keterangan simbol } \\
\text { dapat dilihat pada } \\
\text { tabel } 7\end{array}$ \\
\hline $\begin{array}{l}\text { Rumus Umum } \\
\text { SFD screw } \\
\text { conveyor }\end{array}$ & $V_{x}=R_{A y}-\left(F_{1} x\right)$ & $V_{\max }=128,9 \mathrm{~N}$ & $\begin{array}{c}\text { Keterangan simbol } \\
\text { dapat dilihat pada } \\
\text { tabel } 7\end{array}$ \\
\hline $\begin{array}{l}\text { Rumus umum } \\
\text { BMD conveyor } \\
\text { belt }\end{array}$ & $M_{x}=\left(R_{A y} x\right)-\left(\frac{F_{2} x^{2}}{2}\right)$ & $\begin{array}{l}M_{2 \max } \\
=319,4 \mathrm{Nm}\end{array}$ & $\begin{array}{c}\text { Keterangan simbol } \\
\text { dapat dilihat pada } \\
\text { tabel } 7\end{array}$ \\
\hline $\begin{array}{c}\text { Rumus Umum } \\
\text { SFD conveyor } \\
\text { belt }\end{array}$ & $V_{x}=R_{A y}-\left(F_{2} x\right)$ & $V_{\max }=387,1 \mathrm{~N}$ & $\begin{array}{c}\text { Keterangan simbol } \\
\text { dapat dilihat pada } \\
\text { tabel } 7\end{array}$ \\
\hline
\end{tabular}

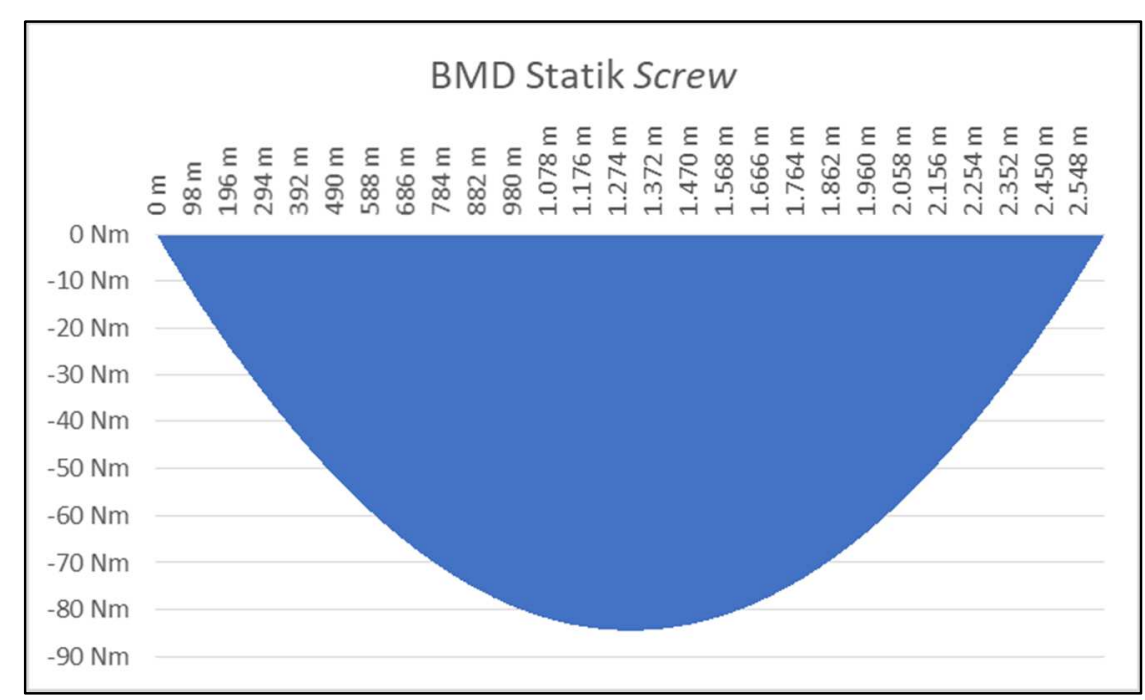

Gambar 6. BMD Statik Screw

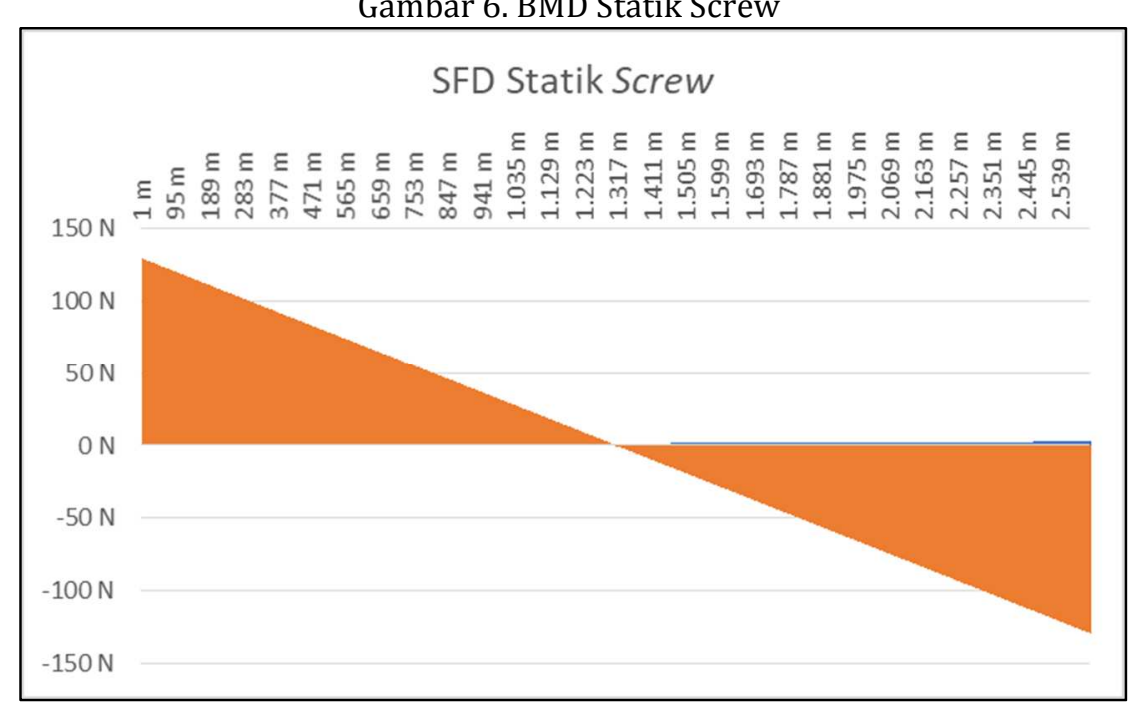

Gambar 7. SFD Statik Screw 
Catur Harsito, Conveyor Pengangkut Sampah Otomatis dengan...

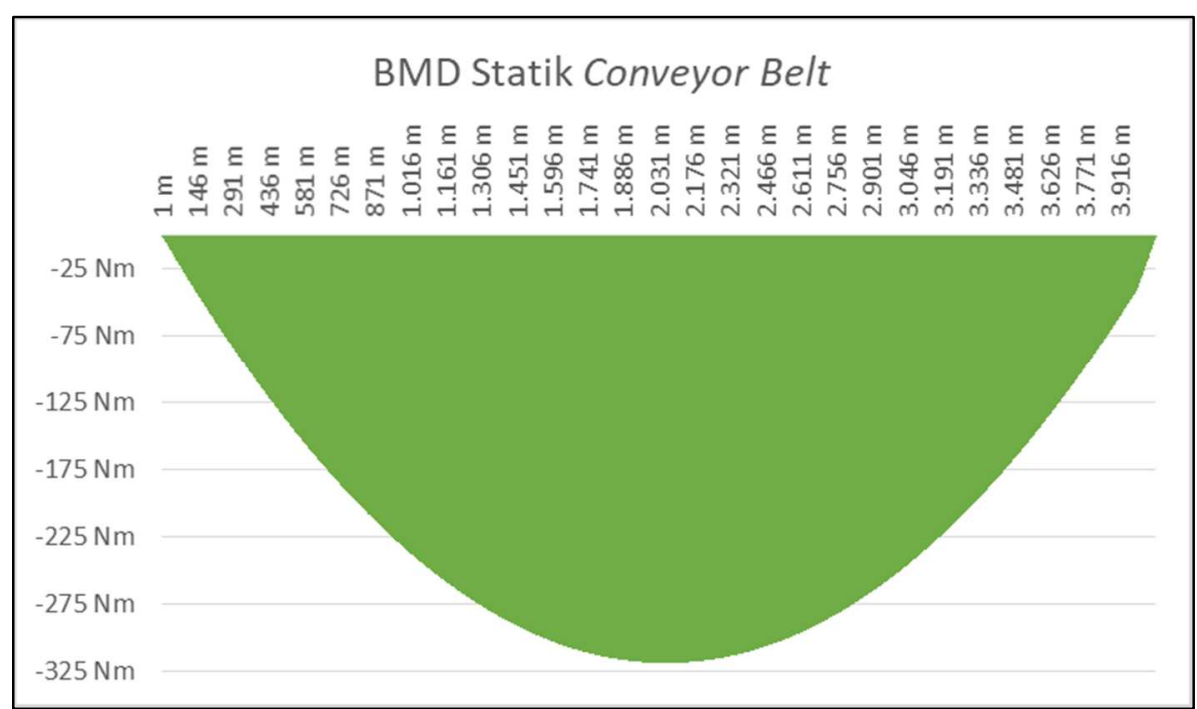

Gambar 8. BMD Conveyor Belt

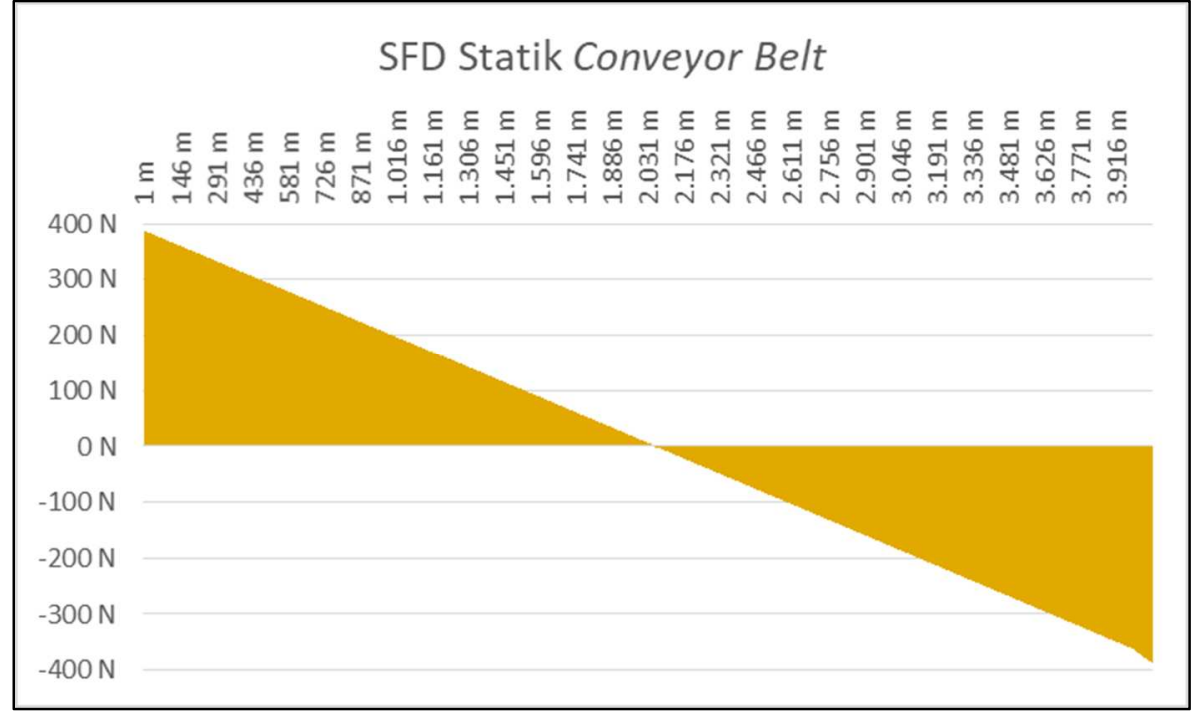

Gambar 9. SFD Statik Conveyor Belt

Pada Gambar 6, Gambar 7, Gambar 8 dan Gambar 9 menunjukkan hasil analisa BMD dan SFD dari screw dan juga conveyor belt. Setelah melakukan analisa statis pada kedua bagian conveyor. Untuk menentukan tegangan menggunakan luas penampang pada titik kritis alat agar dapat mengetahui tegangan maksimum alat. Pada bagian screw conveyor, bagian yang menjadi titik kritis adalah poros screw tersebut,

Tabel 9. Bagan perhitungan tegangan alat

\begin{tabular}{cccc}
\hline Parameter & Rumus & Hasil & Keterangan \\
\hline $\begin{array}{c}\text { Luas penampang poros } \\
\text { roller }\end{array}$ & $A_{2}=\frac{\pi d_{r}^{2}}{4}$ & $4,91 \times 10^{-4} \mathrm{~m}^{2}$ & $d_{r}=25 \mathrm{~mm}$ \\
\hline $\begin{array}{c}\text { Luas penampang poros } \\
\text { screw }\end{array}$ & $A_{2}=\frac{\pi d_{s}^{2}}{4}$ & $1,96 \times 10^{-3} \mathrm{~m}^{2}$ & $d_{s}=50 \mathrm{~mm}$ \\
\hline $\begin{array}{c}\text { Beban maksimum yang } \\
\text { di terima poros roller }\end{array}$ & $F_{r}=M_{2 \max } \frac{l_{2}}{2}$ & $527,01 \mathrm{~N}$ & $\begin{array}{c}\text { Keterangan simbol } \\
\text { dapat dilihat pada } \\
\text { tabel 7 dan 8 }\end{array}$ \\
\hline
\end{tabular}




\begin{tabular}{cccc}
\hline $\begin{array}{c}\text { Beban maksimum yang } \\
\text { di terima poros screw }\end{array}$ & $F_{S}=M_{1 \max } \frac{l_{1}}{2}$ & $110,564 \mathrm{~N}$ & $\begin{array}{c}\text { Keterangan simbol } \\
\text { dapat dilihat pada } \\
\text { tabel 7 dan 8 }\end{array}$ \\
\hline $\begin{array}{c}\text { Tegangan pada poros } \\
\text { roller }\end{array}$ & $\sigma_{2}=\frac{F_{r}}{A_{2}}$ & $1,1 \mathrm{MPa}$ & \\
\hline $\begin{array}{c}\text { Tegangan pada poros } \\
\text { screw }\end{array}$ & $\sigma_{1}=\frac{F_{s}}{A_{1}}$ & $0,6 \mathrm{MPa}$ & \\
\hline
\end{tabular}

Pada Tabel 10, menunjukkan hasil nilai perhitungan tegangan alat. Nilai tersebut akan digunakan sebagai pemilihan material rancangan conveyor belt. Berdasarkan tabel 11, beban yang diterima alat tidaklah terlalu signifikan sehingga penulis memutuskan untuk menggunakan material yang terjual di pasaran dan biasa di pakai dalam industri. Pada bagian conveyor belt, bagian badan conveyor terdiri dari baja ringan dan plat baja. Belt yang digunakan adalah belt PVC yang terjual banyak di pasaran. Sedangkan, bagian screw conveyor terbuat dari HDPE karena densitasnya yang mirip air yaitu $0,954 \mathrm{~g} / \mathrm{cm}^{3}$ [15].

Tabel 10. Kekuatan Material

\begin{tabular}{clll}
\hline & Material & Mpa (ty) & Mpa (tg) \\
\hline Famous & Low alloy steels & $400-1100$ & $460-1200$ \\
\hline & Polymere & Mpa (ty) & Mpa (tg) \\
\hline Thermoplastic & Polyethylene (PC) & $17,9-29$ & $20,7-44,8$ \\
\hline & PVC & $35,4-52,1$ & $40,7-65,1$ \\
\hline
\end{tabular}

Sumber : [16]

Pada bagian screw conveyor safety factornya minimal adalah 4,6. Sedangkan, safety factor pada bagian conveyor belt adalah minimal 15. Hasil simulasi alat juga menunjukkan tidak ada deformasi yang berbahaya atau dapat mengurangi performa kerja alat.

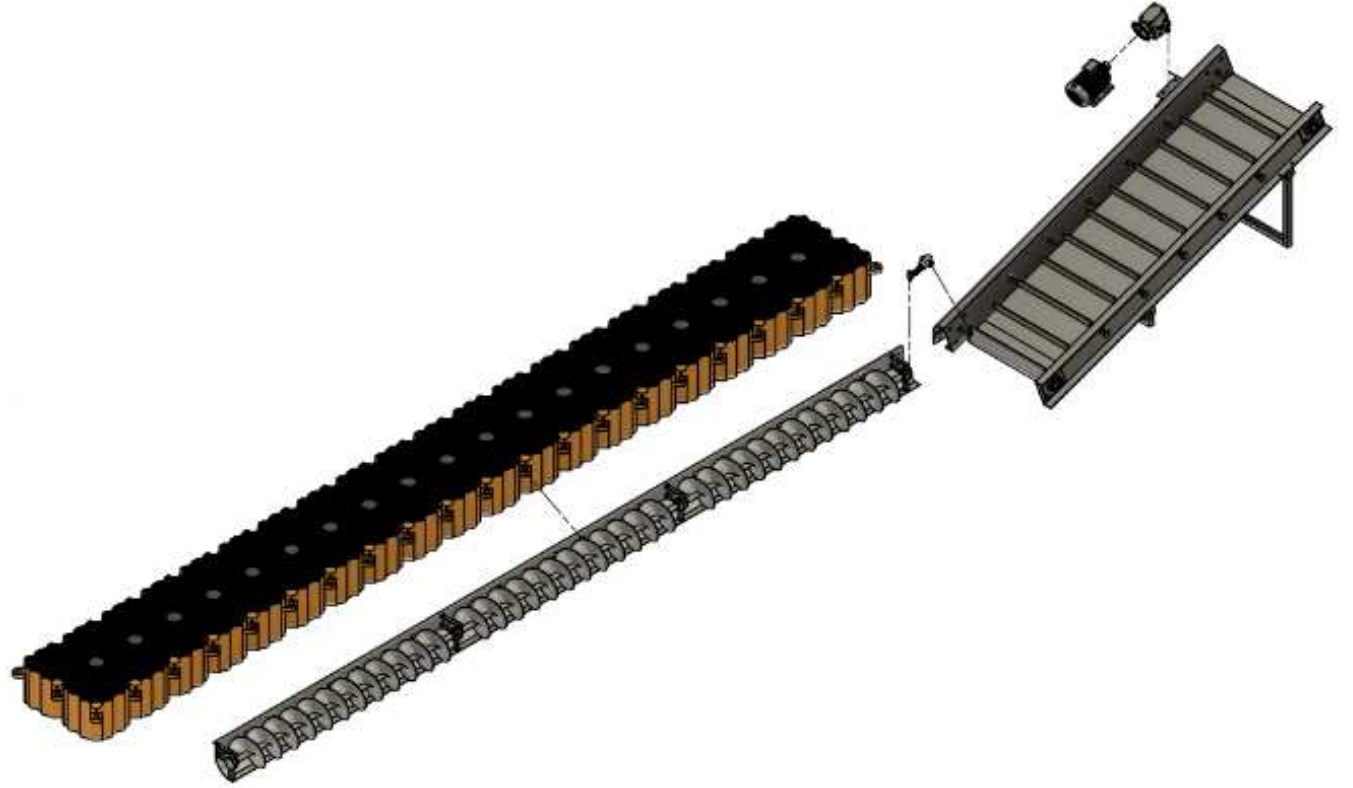

Gambar 10 Exploded View

Pada Gambar 10, adalah rancangan akhir dari alat. Setelah rancangan selesai, di perlukan analisis DFMA (Design For Manufacture and Assembly) dan permesinan untuk merencanakan proses produksi dan perakitan dari alat pengangkat sampah yang sudah 
penulis buat. Analisis DFMA akan dibuat dalam bentuk tabel. Dengan membuat tabel analisis DFMA maka dapat diketahui berapa tingkat kerumitan ketika dilakukan perakitan pada alat tersebut. Semakin mudah perakitan pada alat tersebut maka akan semakin baik. Tabel DFMA tersebut dapat di lihat pada Tabel 11. Penulis juga telah merencanakan proses permesinan yang akan dilakukan pada bagian - bagian rancangan ini sesuai kebutuhan. Beberapa alat yang sudah ada di pasaran akan di beli sehingga mengurangi biaya dan waktu untuk permesinan Proses permesinan yang akan dilakukan diperlihatkan pada Tabel 12. 
JMEMME, 5 (1)(2021): 18 -

Tabel 11. DFMA Part

\begin{tabular}{|c|c|c|c|c|c|c|c|c|c|c|c|c|c|c|c|c|c|c|}
\hline \multirow[b]{2}{*}{ 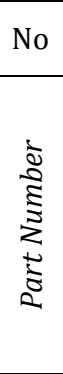 } & \multirow[t]{2}{*}{ Part } & \multicolumn{2}{|c|}{$\begin{array}{c}D F A \\
\text { Complexity } \\
\end{array}$} & \multicolumn{2}{|c|}{$\begin{array}{c}\text { functional } \\
\text { analysis }\end{array}$} & \multirow[b]{2}{*}{ 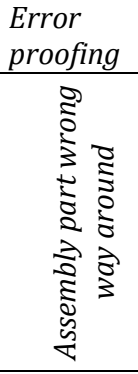 } & \multicolumn{3}{|c|}{ handling } & \multicolumn{4}{|c|}{ insertion } & \multicolumn{5}{|c|}{ assembly } \\
\hline & & 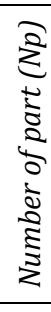 & 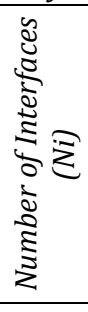 & 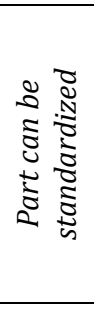 & 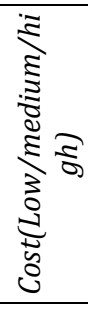 & & 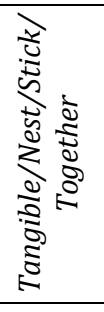 & 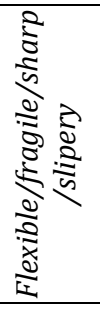 & 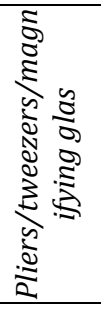 & 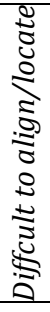 & 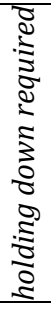 & 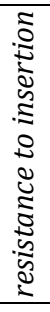 & 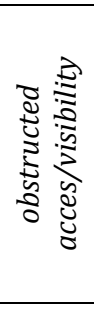 & 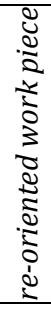 & 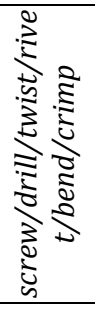 & $\begin{array}{l}\frac{5}{5} \\
\frac{2}{2} \\
\frac{2}{2} \\
\frac{0}{2} \\
\frac{2}{3}\end{array}$ & 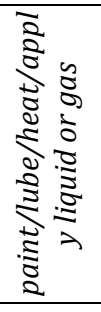 & 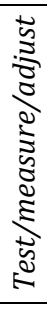 \\
\hline 1 & Batang penyangga & 7 & 3 & $\mathrm{~N}$ & $\mathrm{~L}$ & $\mathrm{Y}$ & $\mathrm{Y}$ & $\mathrm{N}$ & $\mathrm{N}$ & $\mathrm{N}$ & $\mathrm{Y}$ & $\mathrm{N}$ & $\mathrm{N}$ & $\mathrm{Y}$ & Y & $\mathrm{N}$ & $\mathrm{N}$ & $\mathrm{Y}$ \\
\hline 2 & Roller & 7 & 2 & Y & $\mathrm{L}$ & Y & $\mathrm{N}$ & $\mathrm{N}$ & $\mathrm{N}$ & $\mathrm{N}$ & $\mathrm{N}$ & $\mathrm{N}$ & $\mathrm{N}$ & $\mathrm{N}$ & $\mathrm{N}$ & $\mathrm{N}$ & $\mathrm{N}$ & $\mathrm{N}$ \\
\hline 3 & Cover Conveyor Kanan & 1 & 3 & $\mathrm{Y}$ & $\mathrm{L}$ & $\mathrm{N}$ & $\mathrm{N}$ & $\mathrm{N}$ & $\mathrm{N}$ & $\mathrm{N}$ & $\mathrm{N}$ & $\mathrm{N}$ & $\mathrm{N}$ & $\mathrm{N}$ & $\mathrm{N}$ & $\mathrm{N}$ & $\mathrm{N}$ & $\mathrm{Y}$ \\
\hline 4 & Cover Conveyor Kiri & 1 & 3 & $\mathrm{Y}$ & $\mathrm{L}$ & $\mathrm{N}$ & $\mathrm{N}$ & $\mathrm{N}$ & $\mathrm{N}$ & $\mathrm{N}$ & $\mathrm{N}$ & $\mathrm{N}$ & $\mathrm{N}$ & $\mathrm{N}$ & $\mathrm{N}$ & $\mathrm{N}$ & $\mathrm{N}$ & $\mathrm{Y}$ \\
\hline 5 & Penyangga mesin & 1 & 1 & $\mathrm{~N}$ & $\mathrm{~L}$ & $\mathrm{~N}$ & $\mathrm{Y}$ & $\mathrm{N}$ & $\mathrm{N}$ & $\mathrm{N}$ & $\mathrm{Y}$ & $\mathrm{N}$ & $\mathrm{N}$ & $\mathrm{Y}$ & Y & $\mathrm{N}$ & $\mathrm{N}$ & Y \\
\hline 6 & Belt & 1 & 2 & $\mathrm{~N}$ & $\mathrm{~L}$ & Y & $\mathrm{Y}$ & $\mathrm{N}$ & $\mathrm{N}$ & $\mathrm{N}$ & $\mathrm{N}$ & $\mathrm{N}$ & $\mathrm{N}$ & $\mathrm{N}$ & $\mathrm{N}$ & $\mathrm{N}$ & $\mathrm{N}$ & $\mathrm{Y}$ \\
\hline 7 & Roller Support & 4 & 12 & $\mathrm{~N}$ & $\mathrm{~L}$ & Y & $\mathrm{N}$ & Y & $\mathrm{N}$ & $\mathrm{N}$ & $\mathrm{N}$ & $\mathrm{N}$ & $\mathrm{N}$ & $\mathrm{N}$ & $\mathrm{N}$ & $\mathrm{N}$ & $\mathrm{N}$ & $\mathrm{N}$ \\
\hline 8 & Speed reducer & 1 & 2 & $\mathrm{Y}$ & $\mathrm{L}$ & Y & $\mathrm{N}$ & $\mathrm{N}$ & $\mathrm{N}$ & $\mathrm{N}$ & $\mathrm{N}$ & $\mathrm{N}$ & $\mathrm{N}$ & $\mathrm{N}$ & $\mathrm{N}$ & $\mathrm{N}$ & $\mathrm{N}$ & $\mathrm{N}$ \\
\hline 9 & $\mathrm{AC}$ induction motor & 1 & 1 & $\mathrm{Y}$ & $\mathrm{L}$ & Y & $\mathrm{N}$ & $\mathrm{N}$ & $\mathrm{N}$ & $\mathrm{N}$ & $\mathrm{N}$ & $\mathrm{N}$ & $\mathrm{N}$ & $\mathrm{Y}$ & $\mathrm{N}$ & $\mathrm{Y}$ & $\mathrm{N}$ & $\mathrm{N}$ \\
\hline 10 & Kubus apung & 40 & 193 & $\mathrm{Y}$ & $\mathrm{H}$ & $\mathrm{N}$ & $\mathrm{Y}$ & $\mathrm{N}$ & $\mathrm{N}$ & $\mathrm{N}$ & $\mathrm{N}$ & $\mathrm{N}$ & $\mathrm{N}$ & $\mathrm{N}$ & $\mathrm{N}$ & $\mathrm{N}$ & $\mathrm{Y}$ & $\mathrm{N}$ \\
\hline 11 & $\begin{array}{l}\text { Pin connector kubus } \\
\text { apung }\end{array}$ & 19 & 76 & Y & $\mathrm{L}$ & $\mathrm{N}$ & Y & $\mathrm{N}$ & $\mathrm{N}$ & $\mathrm{N}$ & $\mathrm{N}$ & $\mathrm{N}$ & $\mathrm{N}$ & $\mathrm{N}$ & $\mathrm{N}$ & $\mathrm{N}$ & $\mathrm{N}$ & $\mathrm{N}$ \\
\hline 12 & cover screw conveyor & 1 & 2 & $\mathrm{~N}$ & $\mathrm{~L}$ & $\mathrm{Y}$ & $\mathrm{N}$ & $\mathrm{N}$ & $\mathrm{N}$ & $\mathrm{N}$ & $\mathrm{N}$ & $\mathrm{N}$ & $\mathrm{N}$ & $\mathrm{N}$ & Y & $\mathrm{N}$ & $\mathrm{N}$ & $\mathrm{N}$ \\
\hline 13 & Screw & 3 & 3 & $\mathrm{Y}$ & $\mathrm{L}$ & $\mathrm{N}$ & $\mathrm{N}$ & $\mathrm{N}$ & $\mathrm{N}$ & $\mathrm{N}$ & $\mathrm{N}$ & $\mathrm{N}$ & $\mathrm{N}$ & $\mathrm{N}$ & $\mathrm{N}$ & $\mathrm{N}$ & $\mathrm{N}$ & $\mathrm{N}$ \\
\hline 14 & penyambung screw akhir & 1 & 1 & Y & $\mathrm{L}$ & $\mathrm{N}$ & $\mathrm{N}$ & $\mathrm{N}$ & $\mathrm{N}$ & $\mathrm{N}$ & $\mathrm{N}$ & $\mathrm{N}$ & $\mathrm{N}$ & $\mathrm{N}$ & $\mathrm{N}$ & $\mathrm{N}$ & $\mathrm{N}$ & $\mathrm{N}$ \\
\hline 15 & $\begin{array}{c}\text { penyambung screw } \\
\text { antara }\end{array}$ & 3 & 6 & Y & $\mathrm{L}$ & $\mathrm{N}$ & $\mathrm{N}$ & $\mathrm{N}$ & $\mathrm{N}$ & $\mathrm{N}$ & $\mathrm{N}$ & $\mathrm{N}$ & $\mathrm{N}$ & $\mathrm{N}$ & $\mathrm{N}$ & $\mathrm{N}$ & $\mathrm{N}$ & $\mathrm{N}$ \\
\hline 16 & transmisi & 1 & 2 & $\mathrm{Y}$ & M & $\mathrm{N}$ & $\mathrm{N}$ & $\mathrm{N}$ & $\mathrm{N}$ & $\mathrm{N}$ & $\mathrm{N}$ & $\mathrm{N}$ & $\mathrm{N}$ & $\mathrm{Y}$ & $\mathrm{N}$ & $\mathrm{Y}$ & $\mathrm{N}$ & $\mathrm{N}$ \\
\hline 17 & load cell & 3 & 2 & Y & M & Y & Y & $\mathrm{N}$ & $\mathrm{N}$ & $\mathrm{N}$ & $\mathrm{Y}$ & $\mathrm{N}$ & $\mathrm{N}$ & $\mathrm{N}$ & $\mathrm{N}$ & $\mathrm{N}$ & $\mathrm{N}$ & $\mathrm{N}$ \\
\hline 18 & flow censor & 3 & 2 & $\mathrm{Y}$ & M & Y & Y & $\mathrm{N}$ & $\mathrm{N}$ & $\mathrm{N}$ & $\mathrm{Y}$ & $\mathrm{N}$ & $\mathrm{N}$ & $\mathrm{N}$ & $\mathrm{N}$ & $\mathrm{N}$ & $\mathrm{N}$ & $\mathrm{N}$ \\
\hline
\end{tabular}


Catur Harsito, Conveyor Pengangkut Sampah Otomatis dengan...

Tabel 12. Machining Part

\begin{tabular}{|c|c|c|c|c|c|c|c|c|c|c|}
\hline $\begin{array}{l}\text { Nomor } \\
\text { Part }\end{array}$ & Nama Part & Tapping & Counterboring & Drilling & Miling & Grinding & Shaping & Fillet & Chamfer & Other \\
\hline 1 & Batang penyangga & M10 M3 & $\mathrm{N}$ & $\mathrm{Y}$ & $\mathrm{N}$ & $\mathrm{Y}$ & $\mathrm{Y}$ & $\mathrm{N}$ & $\mathrm{N}$ & \\
\hline 2 & Roller & & & & & & & & & Purcahsed \\
\hline 3 & $\begin{array}{l}\text { Cover conveyor } \\
\text { kanan }\end{array}$ & M6 & $\mathrm{N}$ & $\mathrm{Y}$ & $\mathrm{N}$ & $\mathrm{Y}$ & $\mathrm{Y}$ & $\mathrm{N}$ & $\mathrm{N}$ & \\
\hline 4 & Cover conveyor kiri & M6 & $\mathrm{N}$ & $\mathrm{Y}$ & $\mathrm{N}$ & $\mathrm{Y}$ & $\mathrm{Y}$ & $\mathrm{N}$ & $\mathrm{N}$ & \\
\hline 5 & Penyangga mesin & M10 & $\mathrm{N}$ & $\mathrm{Y}$ & $\mathrm{N}$ & $\mathrm{Y}$ & $\mathrm{Y}$ & $\mathrm{N}$ & $\mathrm{N}$ & \\
\hline 6 & Belt & & & & & & & & & Purcahsed \\
\hline 7 & Roller support & & & & & & & & & Purcahsed \\
\hline 8 & Speed reducer & & & & & & & & & Purcahsed \\
\hline 9 & AC induction motor & & & & & & & & & Purcahsed \\
\hline 10 & Kubus apung & & & & & & & & & Purcahsed \\
\hline 11 & $\begin{array}{c}\text { Pin connector kubus } \\
\text { apung }\end{array}$ & & & & & & & & & Purcahsed \\
\hline 12 & Cover screw conveyor & M6 & $\mathrm{N}$ & $\mathrm{Y}$ & $\mathrm{N}$ & $\mathrm{Y}$ & $Y$ & $\mathrm{~N}$ & $\mathrm{~N}$ & \\
\hline 13 & Screw & & & & & & & & & Purcahsed \\
\hline 14 & $\begin{array}{c}\text { Penyambung screw } \\
\text { akhir }\end{array}$ & & & & & & & & & Purcahsed \\
\hline 15 & $\begin{array}{c}\text { Penyambung screw } \\
\text { antara }\end{array}$ & & & & & & & & & Purcahsed \\
\hline 16 & Transmisi & & & & & & & & & Purcahsed \\
\hline 17 & Load cell & & & & & & & & & Purcahsed \\
\hline 18 & Flow censor & & & & & & & & & Purcahsed \\
\hline
\end{tabular}




\section{KESIMPULAN}

Berdasarkan uraian-uraian yang telah dikemukakan sebelumnya, maka dapat ditarik kesimpulan, yaitu pada perancangan Conveyor Pengangkut Sampah dengan Load Cell dan Flow Censor sebagai Indikator Kecepatan Pengangkatan Sampah Otomatis memiliki batang penyangga, roller, cover conveyer belt kanan dan kiri, penyangga mesin, belt, roller support, speed reducer, AC induction motor, kubus apung, pin connector kubus apung, cover screw conveyor, screw, bridge akhir, pebdridge antara, transmisi, load cell dan flow cencor. Kemudian terkait dengan pengurangan biaya perancangan dilakukan pembelian komponen dipasaran antara lain sebagai berikut : roller, belt, roller support, speed reducer, AC induction motor, kubus apung, pin connector kubus apung, screw, bridge akhir, pebdridge antara, transmisi, load cell dan flow censor. Saran yang dapat diberikan bagi peneliti selanjutnya adalah melakukan inovasi pada perancangan conveyor menggunakan sasaran sungai yang luas dan mampu menampung berat lebih dari conveyor rancangan ini.

\section{REFERENSI}

[1] A. Nugraha, S. H. Sutjahjo, and A. A. Amin, “Analisis Persepsi Dan Partisipasi Masyarakat Terhadap Pengelolaan Sampah Rumah Tangga Di Jakarta Selatan,” J. Pengelolaan Sumberd. Alam dan Lingkung. (Journal Nat. Resour. Environ. Manag., vol. 8, no. 1, pp. 7-14, 2018.

[2] L. Penny, U. Bijaksana, R. Yunita, and D. Itta, "Kajian Perilaku Masyarakat Membuang Sampah Di Bantaran Sungai Martapura Terhadap Lingkungan Perairan,” EnviroScienteae, vol. 8, pp. 117-126, 2012.

[3] A. Surya, "Pemanfaatan Mesin Penghancur Sampah Organik Untuk Memproduksi Pakan Bagi Maggot," J. Mech. Eng. Manuf. Mater. Energy, vol. 4, no. 1, pp. 31-39, 2020.

[4] A. S. Surya, F. Azharul, and W. Arso, "Rancang Bangun Alat Penghancur Sampah Organik Skala Rumah Tangga," J. Mech. Eng. Manuf. Mater. Energy, vol. 3, no. 2, p. 92, 2019.

[5] M. Y. Yuhazri, A. J. Zulfikar, and A. Ginting, "Fiber Reinforced Polymer Composite as a Strengthening of Concrete Structures?]: A Review Fiber Reinforced Polymer Composite as a Strengthening of Concrete Structures?: A Review," in Materials Science and Engineering, 2020, p. 13.

[6] O. Kaplan and C. Celik, "An experimental research on woodchip drying using a screw conveyor dryer," Fuel, vol. 215, no. September 2017, pp. 468-473, 2018.

[7] A. J. Zulfikar, "Numerical Analysis of Strength of Rear Brake Holder Flat," J. Mech. Eng. Manuf. Mater. Energy, vol. 2, no. 1, pp. 1-6, 2018.

[8] A. J. Zulfikar, "The Flexural Strength of Artificial Laminate Composite Boards made from Banana Stems," Budapest Int. Res. Exact Sci. J., vol. 2, no. 3, pp. 334-340, 2020.

[9] S. Sariyusda, "Analisis Reliability Centered Maintenance (RCM) Rel Conveyor pada Mesin Oven BTU Pyramax 150N di PT. Flextronics Teknology Indonesia - Batam,” J. Mech. Eng. Manuf. Mater. Energy, vol. 2, no. 1, p. 33, 2018.

[10] A. J. Zulfikar, "Numerical Simulation on The Onion Dryer Frame Capacity of 5 kg/hour," JMEMME, vol. 2, no. 02, pp. 86-92, 2018.

[11] D. Mondal, "Study on Filling Factor of Short Length Screw Conveyor With Flood-Feeding," in Materials Today: Proceedings, 2018, vol. 5, no. 1, pp. 1286-1291.

[12] D. Minglani, A. Sharma, H. Pandey, R. Dayal, J. B. Joshi, and S. Subramaniam, “A review of granular fl ow in screw feeders and conveyors," Powder Technol., vol. 366, pp. 369-381, 2020.

[13] R. N. Yusfi and T. P. Damanhur, "Study Of Solid Waste Characteristics And Recycle Potential In Cikapundung Riverbanks,” J. Tek. Lingkung., vol. 18, no. 2, pp. 155-166, 2012. 
Catur Harsito, Conveyor Pengangkut Sampah Otomatis dengan...

[14] A. Glowacz and Z. Glowacz, "Diagnosis of the three-phase induction motor using thermal imaging," Infrared Phys. Technol., vol. 81, pp. 7-16, 2017.

[15] W. Tang, M. H. Santare, and S. G. Advani, "Melt processing and mechanical property characterization of multi-walled carbon nanotube/high density polyethylene (MWNT/HDPE) composite films," Carbon N. Y., vol. 41, no. 14, pp. 2779-2785, 2003.

[16] J. G. Kaufman, Mechanical Engineers Handbook: Materials and Mechanical Design, 3rd ed. New York: John Wiley \& Sons, Inc., 2006. 